\title{
Flawed Foundations: The Philosophical Critique of (a Particular Type of) Economics
}

\author{
Martha C. Nussbaum $\dagger$
}

The success of Law and Economics obscures, to some extent, a striking fact: the movement has virtually ignored criticisms of its foundations that are increasingly influential in mainstream economics, and by now commonplace (at least as points to grapple with) in utilitarian philosophy. These criticisms are hardly new-indeed, in philosophy most of them have been around since the fourth century B.C., when Aristotle criticized Plato's ambitious attempt to propose a "science of measurement" dealing with ethical value. By not informing itself about, and confronting, these criticisms, Law and Economics, which typically sees itself as a forward-looking and scientific movement, risks being stuck in the confusions that plagued philosophy during that interesting century.

Law and Economics could be understood as involving simply a commitment to bring economics to bear upon law. So understood, the project would involve no particular claims about the proper foundations for economics. It would be as compatible with Amartya Sen's neo-Aristotelian conceptions as with those used by the "Chicago School," as hospitable to Adam Smith's complex cognitive analyses of emotion (based on Aristotle and the Stoics) as to the various views of preference and desire more commonly found in neoclassical economics. But in fact, although recently the movement has become somewhat broader, taking more account of approaches such as those of Sen and Smith, Law and Economics has been built on a particular set of conceptual foundations. These involve at least the following ideas: that rational agents are self-interested maximizers of utility; that utility can best be understood (for explanatory/predictive purposes) as a single item varying only in quantity; that utility is best analyzed in terms of the satisfaction of preferences; that preferences are exogenous, i.e., not significantly shaped by laws and institutions; and that the ends adopted by an agent cannot themselves be the

$\dagger$ Ernst Freund Professor of Law and Ethics, The University of Chicago Law School, Philosophy Department, and Divinity School. I would like to thank Douglas Baird, Richard Posner, Mark Ramseyer, and Cass Sunstein for their helpful comments on an earlier draft, and Ross Davies for invaluable research assistance. 
subject of rational deliberation, although agents may deliberate about instrumental means to ends. All these ideas were at one time unchallenged in mainstream neoclassical economics; all are currently contested, in part as the result of pressure from philosophy and its history.

The topic of endogenous preferences has received considerable discussion within the Law and Economics movement, and has by now become a major topic of the work of Gary Becker, one of the movement's mentors. I shall therefore discuss it here only where it impinges on one of my other topics. I do think it significant, however, that the endogeneity of preferences has been recognized by almost all the major writers on emotion and desire in the history of Western philosophy, including Plato, Aristotle, the Epicureans, the Stoics, Thomas Aquinas, Spinoza, and Adam Smith, not to mention countless contemporary writers in philosophy and in related fields (such as anthropology and cognitive psychology). It is therefore a sign of the problem I am discussing that Becker and others entertained this idea only recently, when work on phenomena such as addiction made its importance obvious, despite the fact that it had importance as well for earlier work on human capital formation. ${ }^{1}$ Adam Smith evidently believed that a pretty good way for an economist to spend his life was to teach and read a great deal of philosophy; he may have been right.

Let me now, however, turn to seven issues less frequently discussed where the same problem, I believe, obtains: powerful philosophical arguments that cast doubt on current foundations are being ignored. As we proceed, it is important to bear in mind that Law and Economics is, in effect, both an explanatory/predictive and a normative theory. Typically it presents itself as explanatory/predictive; but through a certain characteristic use of the concept of rationality, it ends up making normative judgments as well. Thus Richard Posner, for example, both characterizes (most) human behavior as rational in the precise descriptive sense he gives to that term, and then, shifting over to a normative use of the same term, blames certain other agents for not conforming their behavior to those standards. ${ }^{2}$ I shall at-

1 Becker now states that discrimination on the basis of race and sex can cause people to form low aspirations and hopes, and therefore to underinvest in their human capital. See Gary S. Becker, Nobel Lecture: The Economic Way of Looking at Behavior, $101 \mathrm{~J}$ Pol Econ 385 (1993). We should not congratulate people for rediscovering something whose predictive importance has already been discovered and convincingly defended by others, if the arguments of those others were publicly available.

2 See, for example, Richard A. Posner, The Economics of Justice (Harvard 1983), where Posner first makes the assumption that people are "rational maximizers of their 
tempt to distinguish these two uses of the theory wherever that is possible and relevant. My economic examples will generally be drawn from the areas with which my work has made me most familiar: development and welfare.

\section{PLURAL UTILITY AND NON-COMMENSURABILITY}

A commitment to the commensurability of all an agent's ends runs very deep in the Law and Economics movement. Even when a plurality of distinct ends is initially recognized, the underlying view that agents are "maximizers of satisfactions," and that satisfaction is something that varies in degree rather than in kind, leads the theorist rapidly back to the idea that distinctions among options should be understood in terms of the quantity of utility they afford, rather than in terms of any basic qualitative differences. (Thus Posner, having identified three distinct ends of sexual activity, proceeds to treat choices and tradeoffs between them as if they were choices between differing amounts of a homogeneous good. ${ }^{3}$ ) Even though this is not offered as an account of how agents internally view their choices, it is assumed that casting choices this way will allow us to make correct predictions about the behavior of most people.

Plato (and Henry Sidgwick, following his lead) proceeded in just this way, holding that we would have an adequate ethical science only if we did establish it as a "science of measurement," in which all the diverse values that people ordinarily pursue were understood as merely different quantities of a single overarching value. ${ }^{4}$ They took this course because they believed that only in this way could human action be systematized and rendered lawlike. ${ }^{5}$ But they portrayed their project from the start as radically revisionary, rather than explanatory of current behavior: they were offering people a tool by which they could think and act more "scientifically," and hence behave differently-not offering an accurate way of explaining and predicting what real

satisfactions," id at 1, and then goes on to criticize Supreme Court privacy decisions for not conforming to rationality, as he has previously defined it, calling the privacy decisions a "topsy-turvy world." Id at 345 .

${ }^{3}$ Richard A. Posner, Sex and Reason 111 (Harvard 1992) (recognizing three distinct ends); id at 115-42 (discussing tradeoffs in quantitative terms). See also Martha C. Nussbaum, "Only Grey Matter"? Richard Posner's Cost-Benefit Analysis of Sex, 59 U Chi L Rev 1689 (1992).

- See Martha C. Nussbaum, The Fragility of Goodness: Luck and Ethics in Greek Tragedy and Philosophy ch 4 (Cambridge 1986).

${ }_{5}$ The best discussion of Sidgwick's philosophical motivations is in Henry S. Richardson, Practical Reasoning About Final Ends ch 5 (Cambridge 1994). 
people think and do. ${ }^{6}$ Indeed, according to Plato's highly persuasive account, the genuine recognition of values as commensurable would change human action utterly, removing the passionate longing for distinct individuals that gives much of human life a messy character, and even removing the common phenomenon of akrasia, in which an agent judges one course of action better than another but does the worse. Plato convincingly argued that a person who recognized no qualitative distinctions in value would never have this problem, and would therefore behave very differently on a number of important occasions. Following his lead, later philosophers had a great deal to say about the "therapeutic" advantages of commensurability in altering human behavior, removing, for example, many grounds for emotions such as jealousy and anger that currently explain a great deal of human action. Sidgwick, too, insisted that a true utilitarian agent would choose differently from most people, although for complicated reasons he thought that society, to be well coordinated, should contain only a small number of such agents. ${ }^{7}$

If we consider some central texts in Law and Economics, the Plato/Sidgwick claim is borne out: we see the world remade, not the world we live in. For example, Posner's descriptions of human sexuality, in Sex and Reason, do not convey the sense that we are looking at sex the way people generally look at it; instead, a perspective of lofty detachment has flattened and simplified things that are usually messy and real. More important, it would appear that Plato and Sidgwick are correct about the magnitude of the differences: they seem sufficient to affect greatly the model's predictive value. ${ }^{8}$

This criticism (put more generally) is by now a common point in mainstream economics. Invoking John Stuart Mill's version of this ancient point, Amartya Sen, for example, has argued that welfare economists, to have an adequate predictive theory, should understand utility "primarily as a vector (with several distinct components), and only secondarily as some homogeneous magnitude." Such a view will offer, he claims, "a significantly richer descriptive account of a person's well-being," in ways that

\footnotetext{
${ }^{6}$ On Plato, see Martha C. Nussbaum, Love's Knowledge: Essays on Philosophy and Literature ch 3 (Oxford 1990). On Sidgwick, see my discussion in Nussbaum, Fragility at 112-17 (cited in note 4). See also Richardson, Practical Reasoning (cited in note 5).

7 See Nussbaum, Love's Knowledge at 113 (cited in note 6). See also David Wiggins, Weakness of Will, Commensurability, and the Objects of Deliberation and Desire, in Amélie Oksenberg Rorty, ed, Essays on Aristotle's Ethics (California 1980).

${ }^{8}$ See Nussbaum, “Only Grey Matter"?, 59 U Chi L Rev 1689 (cited in note 3) (arguing this point in detail).
} 
make better predictions possible. ${ }^{9}$ Whether these predictive differences are significant enough to affect the usefulness of models remains, of course, an empirical question; the answer may well vary from one area of economics to another. Sen has made a good case, however, for the conclusion that welfare and development economists must confront this issue and produce arguments that either refute his position by applying utility theory to predict messy real world human behavior, or incorporate plural vectors in models that better predict real world behavior. Sen's challenge remains unanswered.

Sen's criticism does not rely on the idea that assumptions must be realistic. Milton Friedman long ago correctly argued that positive economics, like other sciences, can and should use simple assumptions that do not in all respects correspond to the complex phenomenology of real human action. ${ }^{10}$ What is at issue is the question whether the assumptions are too crude, so oversimple that they fail to single out those aspects of the world that are most salient for predictive purposes. Here the Law and Economics movement has tended to follow the views of Karl Popper, who held that even extremely crude assumptions are frequently aids to scientific progress: as experience falsifies them, they are reformulated and progress is made. ${ }^{11}$ But Popper had an extravagant admiration for the hypotheses of the ancient Greek preSocratic philosophers. Thales's dictum that the world is made of water and Heraclitus's opposing claim that everything is fire were to Popper bold conjectures that promoted good prediction and scientific discovery $!^{22}$ Sen's point, in essence, I think, is that the assumption of commensurability is all too like Thales' assumption: too simple to lead to illuminating and pertinent prediction.

If commensurability leads to inadequate explanation and prediction, does it still, as Plato and Sidgwick thought, offer us a normative theory of rationality that will help us remake our world? Again, the philosophical tradition from Aristotle to Mill

9 Amartya Sen, Plural Utility, Proceedings of the Aristotelian Socy 193, 193-215 (1980-81). See also Amartya Sen and Bernard Williams, Introduction, in Amartya Sen and Bernard Williams, eds, Utilitarianism and Beyond (Cambridge 1982), for related criticisms of economic utilitarianism.

${ }^{10}$ Milton Friedman, The Methodology of Positive Economics, in Daniel M. Hausman, ed, The Philosophy of Economics 210, 215-24 (Cambridge 1984). Interestingly enough, Friedman held that the science of sociology does require realistic assumptions. Id at 236.

$"$ See Karl R. Popper, Conjectures and Refutations: The Growth of Scientific Knowledge 241-42 (Routledge 1974). See also Karl R. Popper, The Logic of Scientific Discovery (Hutchinson 1959).

12 Popper, Conjectures at 136-65 (cited in note 11). 
has given us many reasons to question this idea. Complex accounts of reasonable choosing put forward in Aristotle, Mill, and other more recent philosophers show us that there is no good reason to suppose that commensurability is a prerequisite of rational choice in the normative sense..$^{13}$ Furthermore, they show us that to make two ends commensurable when there are good reasons for thinking them distinct in quality is itself a piece of irrationality, one that can frequently be explained just as Plato and Sidgwick explain it: as a reaction against the complexity of life and as the expression of a desire for a purer and cleaner existence. But such reactions are not always rational in the normative sense: they may express hatred of a world that contains surprise and suffering, and a desire to punish those elements of the world that occasion surprise by refusing them the recognition that their qualitative distinctness urges.

One area in which the refusal to recognize plural ends has been especially pernicious is development economics, by now heavily intertwined with law and normative public policy. Until rather recently, "the quality of life" in a nation was assessed simply by enumerating GNP per capita. This crude norm did not even make salient the distribution of wealth and income, and thus routinely gave high marks to nations such as South Africa, with its tremendous inequalities. Still less did it ask about the connection of GNP to other areas of human functioning that are important indicators of quality of life: areas such as life expectancy, infant mortality, educational attainment, and the presence or absence of political liberties. ${ }^{14}$ More recently, a plural-valued approach inspired by Aristotle has begun to have considerable influence on the ways in which international agencies make normative assessments. ${ }^{15}$ This progress needs to be acknowledged in areas of Law and Economics that deal with human welfare.

One corollary of the recognition of qualitatively distinct ends is the recognition of contingent moral dilemmas, conflicts in which one cannot satisfy all the distinct claims that legitimately

${ }^{13}$ See Richardson, Practical Reasoning at ch 6 (cited in note 5). On Aristotle, see Nussbaum, Fragility at ch 10 (cited in note 4); Nussbaum, Love's Knowledge at ch 2 (cited in note 6). On Mill's normative critique of Bentham, see Sen, Plural Utility, Proceedings of the Aristotelian Socy at 193 (cited in note 9).

" See Martha Nussbaum and Amartya Sen, Introduction, in Martha Nussbaum and Amartya Sen, eds, The Quality of Life (Oxford 1993). The Human Development Reports issued by the United Nations Development Programme have used a plural measure based on Sen's work since 1993. See, for example, United Nations Development Programme, Human Development Report 1995 15-23 (Oxford 1995). 14).

${ }^{15}$ See, for example, the United Nations' Human Development Report (cited in note 
demand recognition. Once again, this is an issue that has inspired a large literature in philosophical and, by now, economic accounts of rationality. ${ }^{16}$ It seems reasonable to think that the recognition of such contingent conflicts is both an important part of daily life, influencing behavior in ways that are significant, and also an important part of a normative account of social rationality. Conflicts in which the competing concerns are not in principle irreconcilable, but the conflict arises from the structure of a particular situation, can alert us to the presence of irrationality and/or injustice in our social institutions. ${ }^{17}$ We notice, for example, that although women and men in our own world face many painful conflicts between the demands of child care and the demands of work, this conflict is not intrinsic to the goods involved, and could be either reduced or removed in a world with more public support for parental leave and child care, and less hostility to parenthood in the established structure of careers.

Notice that this kind of recognition of moral dilemmas entails the rejection of the economic principle of the independence of irrelevant alternatives: we make progress by comparing our present set of options (unfavorably) with another imaginable set, in which agents could fulfill all their deepest commitments without conflict. $^{18}$

There are many deep questions here; I have only gestured toward them. They need to be debated in any adequate merger of economics with law.

\section{WELL-BEING AND AGENCY}

Suppose we now supply Law and Economics with a richer account of utility: is that the end of the problem? There are many reasons to think it is not. Utility is standardly considered (for example, by Posner) as a state of the agent, a state of satisfaction. Here Law and Economics follows both Jeremy Bentham and

\footnotetext{
${ }^{16}$ For a long, but only partial, list of modern philosophers who have addressed this concern, see Nussbaum, Fragility at $27 \&$ n 6 (cited in note 4). See also Nussbaum, Love's Knowledge at ch 2 (cited in note 6); Christopher W. Gowans, Innocence Lost: An Examination of Inescapable Moral Wrongdoing (Oxford 1994). In economics, see Amartya Sen, On Ethics and Economics (Blackwell 1987).

17 This point was well made by Hegel, 4 Antigone: The Philosophy of Fine Art (London 1920) (P.B. Osmaston, trans), reprinted in A. and H. Paolucci, eds, Hegel On Tragedy 68, 71 (New York 1975). For contemporary discussion, see Onora O'Neill, Towards justice and virtue: $A$ constructive account of practical reasoning 159 (Cambridge 1996); Ruth Barcan Marcus, Moral Dilemmas and Consistency, $77 \mathrm{~J}$ Phil 121, 121-36 (1980).

${ }^{1 B}$ See my discussion of Arrow in Nussbaum, Love's Knowledge at 64-65 \& n 23 (cited in note 6). See also Sen, Ethics and Economics (cited in note 16); Richardson, Practical Reasoning ch 5 at 111-18 (cited in note 5).
} 
Sidgwick; even if we add a Millean account of the plurality of satisfactions, we are still dealing only with states of well-being. But agents also act and choose, and this makes an explanatory and a moral difference. In addition to states of well-being, people value and pursue their own agency. They do not typically view as equivalent two states of the world, one produced by their own agency and the other not. Aristotle argued that for most people the main thing that makes life worth living is voluntary action, and that people would not choose any amount of contentment if it were not accompanied by space for choice and practical reason: to do so would be to "choose the life of dumb grazing animals."19 Criticizing Bentham, Mill similarly spoke of the difference between Socrates unsatisfied and a pig satisfied. ${ }^{20}$ Any theory that ignores this distinction thus courts gross explanatory inadequacy. (It makes it very difficult to understand why people struggle so hard for various types of freedom and agency, as they clearly do, why for many people in the world of my childhood the slogan "Better dead than Red" had profound explanatory significance, and so forth.) It might be claimed that the value of choice and practical reason can be cashed out in terms of a "psychic good" that can be understood to be a part of utility. But such arguments need to be made; they certainly run the risk of making the concept of utility utterly vacuous and lacking in predictive value. Any approach along these lines must show how it can solve this problem. ${ }^{21}$ Once again, the problem may be more serious for some areas of Law and Economics than for others, but it needs to be addressed.

If a focus on well-being to the exclusion of agency offers inadequate explanations, it seems even more clearly inadequate as a normative theory of rational choice. For it seems normatively irrational (and seems so, indeed, to many of the founders of the Law and Economics movement, with their strong libertarian affiliations) to consider two states of the world equivalent when one involves the liberty of action and the other does not. Again, it

${ }^{19}$ Aristotle, Nicomachean Ethics 1096a1-2, 1098b33-1099a7, 1176a33-35 (Oxford 1894) (I. Bywater, ed); Aristotle, Eudemian Ethics 1215b22-31, 1216a3-8 (Oxford 1991) (R.R. Walzer and J.M. Mingay, eds). See also Martha C. Nussbaum, Aristotle on Human Nature and the Foundations of Ethics, in World, Mind, and Ethics: Essays on the Philosophy of Bernard Williams (Cambridge 1995).

${ }^{20} \mathrm{John}$ Stuart Mill, Utilitarianism, in John Stuart Mill, Utilitarianism, Liberty, and Representative Government (Dutton 1951). Mill's example actually makes two points: one about qualitative differences within satisfactions, and the other about the need to move beyond satisfaction in seeking to understand what agents have reason to pursue.

${ }^{21}$ On Aristotle's approach, see Nussbaum, Fragility at ch 10 (cited in note 4), and, more generally, Amartya Sen, Well-Being, Agency, and Freedom: The Dewey Lectures 1984, 82 J Phil 169 (1985). 
is not my contention that Law and Economics cannot meet this challenge; economics has done so already, in quite a few ways. ${ }^{22}$ But the challenge cannot simply be ignored, and the answer will need to be subtle enough to grapple with the considerable philosophical literature that by now exists on this question. ${ }^{23}$

Like the plurality of ends, the distinct importance of agency is by now routinely recognized in development economics. The dominant approaches of both Amartya Sen and Partha Dasgupta (along with Sudhir Anand, Jean Drèze, and many others) make it a matter of course to recognize distinct domains of human functioning and capability that are not commensurable along a single metric, and with regard to which choice and liberty of agency play a fundamental structuring role. ${ }^{24}$ Moreover, far from being recondite philosophical subtleties, these notions are in common use by international agencies, structuring their ways of measuring welfare and quality of life. ${ }^{25}$ This shows that taking conceptual distinctions seriously does not hobble science or policy; it actually enables both to progress in humanly useful directions.

Neglect of agency brings with it a common corollary: neglect of the separateness of persons as an important issue in personal and social choice. ${ }^{26}$ Sidgwick, for example, proceeded as if the satisfactions of all rational agents could be regarded, for purposes of choice, as fused into a single system; the boundaries between agents were not regarded as salient when one considered how to augment society's total welfare. No philosopher I know of has ever argued that this kind of boundary-neglect provides an adequate explanatory theory, and it is obvious that it does not.

${ }^{2}$ See Sen, Dewey Lectures (cited in note 21). See also Amartya Sen, Choice, Welfare, and Measurement (Blackwell 1982), and, for implications in development economics, see Amartya Sen, Resources, Values, and Development (Cambridge 1984). See also the role played by liberty in Partha Dasgupta, An Inquiry Into Well-Being and Destitution (Clarendon 1994).

${ }^{23}$ Within the utilitarian tradition recently, see James Griffin, Well-Being: Its Meaning, Measurement, and Moral Importance (Oxford 1986).

${ }^{24}$ See Sen, Resources, Values (cited in note 22); Amartya Sen, Commodities and $\mathrm{Ca}$ pabilities (Elsevier Science 1985); Amartya Sen, Freedoms and Needs: An argument for the primacy of political rights, New Republic 31 (Jan 10 \& 17, 1994); Jean Drèze and Amartya Sen, India: Economic Development and Social Opportunity (Oxford 1995); Dasgupta, Inquiry (cited in note 22). See also Human Development Report (cited in note 14).

${ }^{25}$ For an independent defense of similar concepts, see Erik Allardt, Having, Loving, Being: An Alternative to the Swedish Model of Welfare Research, in Nussbaum and Sen, eds, Quality of Life (cited in note 14); Robert Erikson, Descriptions of Inequality: The Swedish Approach to Welfare Research, in Nussbaum and Sen, eds, Quality of Life (cited in note 14). Sen's approach has structured the United Nations Development Programme's Human Development Reports since 1993, with Anand as co-consultant. See Human Development Report (cited in note 14).

${ }^{25}$ This is clearly an issue for well-being too, not just for agency. For reasons of economy, I consider it only here. 
People care deeply about the difference between a pain in their own life and a pain in China (to use Adam Smith's graphic example). ${ }^{27}$ Even Buddhism, in which this disregard of individuation is regarded as normatively superior, presents itself as a revisionary theory that does not offer good accounts of actual behavior. What might, however, be argued is that neglect of boundaries provides a normatively superior theory, by breaking down a kind of irrational egoism that leads us unjustly to rig things in favor of our own position.

This is one of the most difficult issues in moral and political philosophy; I cannot even adequately describe its complexity here. Suffice it to say, however, that much good argument suggests that neglect of boundaries is not the best way to ensure the most relevant and justice-producing impartiality. The separateness of one person from another can be strongly defended as a basic fact for ethics and politics, one that will stop a normative account from justifying one group's extreme misery by pointing to the extreme satisfaction of another group, as classical utilitarians often do $^{28}$ Now there are certainly arguments on both sides here; many thinkers in Law and Economics will probably wish to defend Sidgwick's normative views against the criticisms of John Rawls, T.M. Scanlon, Brian Barry, and others. ${ }^{29}$ But then they will need to grapple with the arguments; this has not yet been done.

\section{LIBERTARIANISM, UTILITARIANISM, PARETIANISM}

Practitioners of Law and Economics typically rely on the ideas of utilitarianism, for example, the idea of wealth maximization. They typically also portray themselves as libertarians, committed to giving personal liberty of choice a strong degree of priority. Finally, they characteristically endorse Pareto optimality as a normative criterion of social choice. But these three views are not all consistent. Insofar as utilitarianism is committed to aggregating utilities across persons and pursuing the greatest total (or average) utility, it is committed to respecting liberty rather less than most libertarians (and most liberals) would wish to do. If infringing political liberties and liberties of expression, speech, and conscience turns out to be what in fact, in some circumstance, maximizes utility, the utilitarian favors that course

\footnotetext{
${ }^{27}$ See Adam Smith, The Theory of Moral Sentiments 136-37 (Liberty Fund 1984). See also R.H. Coase, Adam Smith's View of Man, $19 \mathrm{~J}$ L \& Econ 529 (1976).

${ }^{23}$ See John Rawls, A Theory of Justice $\$ \S 5,30$ (Belknap 1971).

${ }^{2}$ See, for example, id; T.M. Scanlon, Preference and Urgency, 72 J Phil 655 (1975); Brian Barry, Justice as Impartiality (Oxford 1995).
} 
as best. (Obviously, we are focusing on normative issues here.) Libertarians, by contrast, are committed to giving liberty priority even when that does not maximize welfare. It has long been recognized that in this respect the two positions are on a collision course. ${ }^{30}$ One may grant, along with Mill, that liberty frequently does enhance social welfare; ${ }^{31}$ but once one grants the distinction it is implausible to suppose things will always be thus. And if one tries dogmatically to rig things so that restrictions on liberty always result in more utility losses than gains, one is simply robbing the idea of utility-maximizing of any predictive value. This has been belatedly recognized in at least some parts of the Law and Economics movement. For example, Posner has recently stated that his economic approach to the regulation of sexuality is in tension with the normative libertarianism he espouses. ${ }^{32}$ But why did we have to rediscover the wheel? Once again, grasping established distinctions in philosophy would have made more progress possible sooner.

As for the relationship between Pareto optimality and libertarianism, it is much debated. The huge literature by now responding to Amartya Sen's The Impossibility of a Paretian Lib$e r a l^{33}$ has shown, at any rate, that there is no easy way of resolving the tension between the two principles, so long as we do not exclude nosy preferences from the social choice function. Many different approaches have been tried by many philosophers and economists, and we would expect writers in Law and Economics to acquaint themselves with those debates more than they have in fact done.

\section{RATIONAL DELIBERATION ABOUT ENDS}

It is a dogma of neoclassical economics, and of rational choice theory, that we can deliberate rationally only about the instrumental means to ends, and not about the content of ends themselves. This dogma, which relies on the idea that our ends are hard-wired by exogenously given tastes, has been seriously

\footnotetext{
${ }^{30}$ The materials for this point are already in Aristotle and the Stoics, but its clearest formulations are modern. One excellent treatment is in Rawls, $A$ Theory of Justice at $\$ \S$ 28-29 (cited in note 28), for whom that clash is the central reason for rejecting utilitarianism.

${ }^{31}$ John Stuart Mill, On Liberty, in Mill, Utilitarianism, Liberty, and Representative Government (cited in note 20).

2 Richard A. Posner, Overcoming Law 23-24 (Harvard 1995) (granting that economic thinking has "illiberal implications" and that we "cannot make [them] disappear by judicious assignment of rights").

${ }^{33}$ Amartya Sen, The Impossibility of a Paretian Liberal, in Sen, Choice at ch 13 (cited in note 22).
} 
shaken by the recognition of the endogeneity of preferences. The recognition that we have some control over the shaping of our tastes (both through the shaping of laws, policies, and institutions, and through personal self-shaping and the educating of children) must at least make us ponder the question whether this shaping can be done more or less well. But Law and Economics has not deeply investigated this question.

In terms of both explanation and normative argument, this is a flaw. People do deliberate about ends all the time. To give an example close to home, a student who aims at becoming a lawyer does certainly deliberate about instrumental means to that goal: about how to get a good score on the LSAT, about which law schools to apply to, about how to do well once there. But he or she typically deliberates in another way as well, asking what counts as being a good lawyer-is it a matter of making money, or serving the poor, or seeking intellectual stimulation, or some complex mixture of more than one of these? Such deliberations, which seek to specify the content of a vague end, do not have the simple vertical structure of means-ends deliberation. They typically proceed by moving horizontally, consulting other ends the person may have. How much importance does money have in her life? What commitments does she have to social justice? Does she want to have children? And so forth. Notice that all of this will not only lead to a more precise specification of the end, but also to a more refined selection of instrumental means: for it seems plausible to suppose that it will influence her choice of law school and courses of study. At the same time, her deliberations about lawyering will probably also cast new light on her other endsgiving her a sense, for example, of how she might want to specify the vague ends of "having children," "serving justice," and so forth. And of course, in the context of deliberation about other ends-say, having children or serving justice-she may also ask about the whole end of being a lawyer, as to whether it is one she really wishes to pursue. This is how we really do deliberate in life, in this holistic manner that seeks broad coherence and fit among our ends considered as a group. This picture of deliberation was first advanced by Aristotle, and it has recently been prominently revived in some excellent work by David Wiggins and Henry Richardson. ${ }^{34}$

\footnotetext{
${ }^{34}$ See David Wiggins, Deliberation and Practical Reason, in Rorty, ed, Essays on Aristotle's Ethics (cited in note 7); Richardson, Practical Reasoning at ch 10 (cited in note 5). Both give detailed arguments about Aristotle's views that point the reader to all the relevant passages in Aristotle.
} 
Work by Wiggins, Richardson, and others has made it very plausible to suppose that considering the concrete specification of plural, interconnected ends provides a very good description of how real people deliberate, and a fact so central that it seems unlikely to be irrelevant to a model's predictive value.$^{35}$ At any rate, if some area of Law and Economics wants to show that it is predictively insignificant, the argument needs to be made. It also seems clear that we can describe normative criteria for rationality within this type of deliberation. Indeed, it would appear that any deliberation that doesn't include this kind of specificationist approach is bound to be blinkered and (normatively) irrational. Moreover, it can easily be extended to interpersonal deliberation, and thus to social choice. ${ }^{36}$ Once again, Law and Economics cannot afford to proceed as though all these arguments do not exist. If it wishes to rebut them, on either the explanatory or the normative plane, it must first confront them.

\section{PREFERENCE, DESIRE, EMOTION, INTENTION, ACTION}

Law and Economics typically recognizes a rather reduced number of explanatory entities behind human action. Indeed, the capacious category "preference" seems to cover all of the psychological underpinnings of action, both cognitive and conative. At least there is a distinction made between preference and action: following Becker rather than Paul Samuelson, Law and Economics has typically treated preferences as items that have psychological reality and can be individuated to some extent independently of the actions they explain. By proceeding in this way, it has avoided some of the conceptual quagmire that characterizes the Samuelson revealed-preference approach. ${ }^{37}$

But what an impoverished repertory of explanatory entities! Western philosophers, ever since Plato and Aristotle, have agreed that the explanation of human action requires quite a few distinct concepts; these include the concepts of belief, desire, perception, appetite, and emotion-at the very least. Some contemporary philosophers have felt that Aristotle was basically right, and that we do not need any categories other than those he introduced. ${ }^{38}$ Others have not been so satisfied. The Stoics introduced a further notion of impulse (hormê), in the belief that the

\footnotetext{
${ }^{25}$ See Richardson, Practical Reasoning (cited in note 5).

${ }^{36}$ See id at ch 11.

${ }^{37}$ See, for example, Amartya Sen, Internal Consistency of Choice, 61 Econometrica 495 (1993).

${ }^{38}$ See, for example, G.H. von Wright, The Varieties of Goodness (Routledge 1963); Donald Davidson, Essays on Actions and Events (Oxford 1980).
} 
Aristotelian categories did not altogether capture the innate tendency of things to preserve their being. In a related move, Spinoza introduced the idea of conatus, and gave it great prominence. Kant was partial to the notion of inclination (Neigung), feeling that it captured features of emotion and desire not fully included in the Aristotelian/mediaeval framework. Recently some philosophers have argued that the concept of intention is both irreducible to any of the others and an essential part of explaining action. ${ }^{39}$ And of course others have shown an interest in the concepts introduced by psychoanalysis.

These concepts are introduced as basic to explanation and prediction, not simply as concepts that agents actually use. ${ }^{40}$ In addition to these rich beginnings, there have been centuries of very subtle work on each of the Aristotelian notions, asking about the relationship between emotion and belief, between both of these and desire, and so forth. ${ }^{41}$ This work makes the two claims both normative and predictive, saying both what emotions, desires, appetites, and beliefs will sway an ideally rational agent and also how the behavior of someone who is moved by an emotion, for example grief or compassion, is likely to differ from the behavior of a person who is moved by an appetite with no cognitive content-or by rational self-interest. Some especially important predictive consequences lie in the area of education. Philosophers claim that emotions respond to education in a way that is very different from the way in which intellectual calculations and non-cognitive appetites respond, and they predict accordingly the results of different educational strategies. ${ }^{42}$

Here, more than anywhere else, the foundations of Law and Economics look as yet underdeveloped and crude. If we do not even bother to sort out the many different ways in which people (and other animals ${ }^{43}$ ) are moved, how can we hope to have an adequate descriptive, much less a normative, theory? Law and

See Michael E. Bratman, Intentions, Plans, and Practical Reason (Harvard 1987). See also G.E.M. Anscombe, Intention (Cornell 2d ed 1969).

${ }^{40}$ Frequently they will not correspond straightforwardly to the way agents see their actions, and some of the beings whose actions are being explained, such as nonhuman animals, are not thought to have concepts at all.

${ }^{41}$ Emotions are standardly thought to involve complex cognitive content and to be modifiable by the modification of belief; many desires have less cognitive content, and some may resist modification.

4 We can add that non-Western philosophical traditions also have contributed a great deal along these lines. See generally Joel Marks and Roger T. Ames, eds, Emotions in Asian Thought (State of New York 1995); Bimal Krishna Matilal, Perception: An Essay on Classical Indian Theories of Knowledge (Oxford 1986).

43ee Aristotle's De Motu Animalium, proposing a common schema for the explanation of all animal motion. 
Economics has just barely reached the point at which it is able to distinguish between Becker and Samuelson (and this was not always the case); it has not yet put itself onto the map of conceptually respectable theories of human action. This was not so, of course, in the early days of political economy: Adam Smith is one of the greatest thinkers about the relationship between emotion and action, and he seems to have thought that this inquiry (both predictive and normative) was an important part of thinking about the economy and public policy, besides being of intrinsic interest.

\section{THE COMPLEXITY OF ETHICAL MOTIVATION}

If Law and Economics is ignorant of the theories of human action that have been painstakingly elaborated over the course of twenty-four hundred years, it is not terribly likely that it will see all the complexities of the ways in which people are moved by ethical considerations. And in fact it does not. Homo economicus is a self-interested maximizer of his own satisfactions (or, occasionally, a classical utilitarian maximizer of social welfare). Altruism tends to be reduced to a type of egoism, in which people get reputational or psychic goods for themselves. For some time it has been influentially argued within economics that this approach is inadequate, even for predictive purposes: we need to recognize sympathy and commitment as independent sources of motivation. ${ }^{44}$ This is hardly a surprising claim, because it is one that has been argued throughout the history of Western philosophy-starting, again, with Aristotle, who argued that people who die for their friends or family cannot plausibly be said to do so for satisfaction, because they are risking or forfeiting, in the process, all prospect of future satisfaction. A theory that focuses on satisfaction will therefore make bad predictions about what they will do. ${ }^{45}$ Recently these ideas have been receiving striking empirical confirmation: it has been powerfully argued that economic theories could not have predicted that anyone would risk life, family, comfort, and reputation to rescue Jews during the Holocaust. And yet a significant number of people did. ${ }^{46}$ Again, this does not mean that practitioners of Law and Economics need agree with

\footnotetext{
" See Amartya K. Sen, Rational Fools: A Critique of the Behavioral Foundations of Economic Theory, 6 Phil \& Pub Aff 317, 317-44 (1977), reprinted in Sen, Choice, Welfare, and Measurement 84 (cited in note 22).

45 Aristotle, Nicomachean Ethics at 1174a4-8, 1117b10 et seq, 1169a18-b2 (cited in note 19 ).

${ }^{4}$ See Kristen Renwick Monroe, The Heart of Altruism: Perceptions of a Common Humanity (Princeton 1996).
} 
these results, nor does it entail that they cannot show that for their particular purposes in a given project these facts are predictively irrelevant. But then they have some work to do, both empirical and conceptual, to show how they will explain the behavior of such altruists without new conceptual resources.

\section{MODELING THE FAMILY}

All of the conceptual complexities discussed above arise in a strange and fascinating way in the model of the family most influential in the Law and Economics movement, namely Gary Becker's. Whereas for the most part altruism plays a small role in accounts of economic motivation (or is, as I said, reduced to something else), in Becker's account of the family it plays a stunningly central role. The head of the household is assumed to be a beneficent altruist who will adequately take cognizance of all the interests of all family members, in the process of maximizing the utility of the household as a whole. It is likely that altruism is to be understood as elsewhere in Becker's work, as a variety of selfinterest; ${ }^{47}$ nonetheless, its centrality here is striking.

What we have said so far gives us several reasons to be uneasy with this approach, as either an explanatory or a normative account of the way things are. It assumes a rather slender number of motives. (And Becker now says as much. In his 1992 Nobel Prize lecture he points out that "[m]any economists, including me, have excessively relied on altruism to tie together the interests of family members." He suggests that he should have included, as well, motives such as fear, guilt, "and other attitudes. ${ }^{48}$ ) The model treats the concerns of all as an aggregate and the household as a single organic whole, thus neglecting the salience of boundaries between persons. We cannot even find out how A or B are doing, we can only find out how the whole household is doing-and yet we are assured that all is well, because no trade-offs that slight any member's interests will be made. The potential conflict between maximization of well-being and making some members do badly is not stated or faced. What this means is that the model offers no predictions at all, much less correct ones, about a number of very real questions, such as: When there is a food shortage, which children will be fed? How is domestic violence likely to be correlated with household income? What influence does education have on the nutrition of female

${ }^{47}$ See, for example, Gary S. Becker, The Economic Approach to Human Behavior 28393 (Chicago 1976). See also the critique in Monroe, Altruism at 162-64 (cited in note 46).

48 Becker, Nobel Lecture, $101 \mathrm{~J} \mathrm{Pol} \mathrm{Econ} \mathrm{at} 400$ (cited in note 1). 
children? Should we expect the health status of widows in India to be higher or lower than that of widowers? ? $^{49}$

The fact is that the household is far from being a harmonious unit, even when, as may be the case in families, its members love each other. (Oddly, this also is not how economics assumes people usually are, so we have a complex problem of consistency on our hands as well.) Real families contain much altruism, but they also contain conflicts over resources, and different bargaining positions that situate agents differently with respect to those conflicts. We must understand these different bargaining positions before we can make any prediction at all about a wide range of urgent questions of well-being and agency. Such an understanding is also crucial to an adequate normative account of family law, because law is one of the factors that most decisively structures the bargaining positions of such agents-saying who can marry, what divorce involves, what rights wives have against domestic violence and marital rape, what rights children do and don't have, and so forth. In short, the defects in the standard economic model of the family have enormous explanatory and predictive significance, as well as great normative significance when public policy attempts to address these problems.

As Richard Posner valuably recognized in his remarks, this has been a major area of feminist criticism against Law and Economics, and a valid area of criticism. ${ }^{50}$ Moreover, it is not only feminists who have pressed these claims; it is, by now, a large part of the economics profession, where bargaining models have more or less displaced the older organic models as the standard ways of modeling family interactions. As I say, Becker himself has recognized that his model is seriously flawed, although he has not, to my knowledge, endorsed a bargaining model as opposed to an organic model.

These shortcomings are closely bound up with other shortcomings in Law and Economics' conception of its foundations. Neglect personal boundaries, the distinction between agency and well-being, and the diverse varieties of human motivation, and

19 Becker's recent remarks do not indicate that he intends to disaggregate the family into its separate components; apparently he still prefers an organic model in which the motives of the head of the household stand in for the whole, though these motives are now made more complex.

${ }^{50}$ See Amartya Sen, Gender and Cooperative Conflicts, in Irene Tinker, ed, Persistent Inequalities: Women and World Development (Oxford 1990); Bina Agarwal, 'Bargaining' and Gender Relations: Within and Beyond the Household, FCND Discussion Paper, International Food Policy Research Institute (March 1997); Shelley Lundberg and Robert Pollak, Bargaining and Distribution in Marriage, $10 \mathrm{~J}$ Econ Perspectives 139 (1996); Dasgupta, Inquiry Into Well-Being at ch 11 (cited in note 22). 
you are very likely to come out with an impoverished theory of the family. Law and Economics should address this important area of human life, and economists interested in law are doing so already ${ }^{51}$ If practitioners of Law and Economics ignore this work, it will continue to go forward without them.

\section{CONCLUSION}

Aristotle thought that there was conceptual progress in political thought. For when we sit down and sort through all the good and bad arguments our major predecessors have made, we will learn a lot: "Some of these things have been said by many people over a long period of time, others by a few distinguished people; it is reasonable to suppose that none of them has missed the target totally, but each has gotten something or even a lot of things right." ${ }^{\text {252 }}$ Furthermore, we will also be enabled to avoid their errors. Finally, perhaps, we will ourselves make a little progress beyond them. Aristotle also noticed, however, that the passion for science and simplicity frequently lead highly intelligent people into conceptual confusion and an impoverished view of the human world. So he did not think that progress was inevitable, and one of his great arguments for reading was that it could remind us of conceptual complexities we might otherwise efface, in our zeal to make life more tractable than it is.

Science does not have to be impoverished; in fact, it must not be, if it is to deliver perspicuous descriptions, adequate predictions, and, perhaps, helpful normative recommendations. But Law and Economics is currently still somewhat impoverished. It is impoverished because it did not proceed in the way that Aristotle recommends, sitting down with the arguments of eminent predecessors to see what can be learned from their years of labor. Let us hope that this process will soon begin. There would seem to be no better place for it to begin than in Chicago.

\footnotetext{
${ }^{51}$ See, for example, Agarwal, Bargaining (cited in note 50); Bina Agarwal, A field of one's own: Gender and land rights in South Asia (Cambridge 1994).

${ }^{52}$ Aristotle, Nicomachean Ethics at 1098b28-30 (cited in note 19).
} 